ARAŞTIRMA MAKALESI

\title{
Hastanede Yatan Çocuklarda Psikososyal Semptomlar ile Annelerinin Endişe Düzeyleri Arasındaki İlişkinin İncelenmesi
}

\author{
Gonca ÜSTÜN ${ }^{1}$,id Büşra AKAN², (iD Leyla KÜÇÜK ${ }^{3}$
}

${ }^{1}$ Dr. Öğr. Üyesi, Amasya Üniversitesi, Sağlık Bilimleri Fakültesi, Hemşirelik Bölümü, Psikiyatri Hemşireliği Anabilim Dalı, Amasya, Türkiye. ${ }^{2}$ Hemşire, Sancaktepe Şehit Prof. Dr. İlhan Varank Eğitim ve Araştırma Hastanesi, İstanbul, Türkiye.

${ }^{3}$ Prof. Dr., İstanbul Üniversitesi-Cerrahpaşa, Florence Nightingale Hemşirelik Fakültesi, Ruh Sağlığı ve Psikiyatri Hemşireliği Anabilim Dalı, İstanbul, Türkiye.

Öz

Giriş: Hastanede yatmak hem çocukları hem de annelerini psikososyal açıdan etkilemektedir. Çocuklarda görülen psikososyal semptomların ve annelerinde görülen endişenin erken dönemde saptanması, hemşirelerin bu sorunlara yönelik gerekli müdahaleleri planlaması ve uygulaması için oldukça önemlidir. Amaç: Araştırmanın amacı hastanede yatan 6-12 yaş grubu çocuklarda psikososyal semptomları ve annelerinin endişelerini tanımlamak ve aralarındaki ilişkiyi incelemektir. Yöntem: Tanımlayıcı-ilişki arayıcı nitelikteki bu araştırma, Temmuz-Aralık 2019 tarihleri arasında bir eğitim araştırma hastanesinde yapılmıştır. Araştırmanın örneklemini 6-12 yaş grubundaki 120 çocuk ve anneleri oluşturmuştur. Veriler; "Bilgi Formu", "Hastanede Yatan Çocuklarda Psikososyal Semptomları Tanılama Ölçeği", "Ebeveynlerin Endişe Kaynakları Ölçeği”" ile elde edilmiş ve tanımlayıcı istatistikler, Mann Whitney U, Kruskal Wallis H, Spearman korelasyon testleri ile değerlendirilmiştir. Bulgular: Hastanede yatan 6-12 yaş grubu çocukların \%62.5'i erkek, \%68.3'ü 7 günden daha kısa süredir hastanede yatıyor ve \%58.3'ü birden fazla hastanede yatma deneyimi yaşamıştır. Hastanede yatan erkek çocukların Öfke ve Saldırganlık düzeyi daha yüksek bulunmuştur. Çocuğu henüz okula başlamamış ve çocuğunun hastalığ1 7-15 gündür devam eden annelerin endişe düzeyi daha yüksek bulunmuştur. Çocukların hastanede yatmaya bağlı psikososyal semptomları ile annelerinin endişe düzeyleri arasında zayıf düzeyde pozitif yönlü, çocukların yaşı ile psikososyal semptomlar ve annelerinin endişe düzeyleri arasında zayıf düzeyde negatif yönlü anlamlı bir ilişki olduğu saptanmıştır. Sonuç: Hastanede yatan çocuklarda psikososyal semptomların ve annelerinde görülen endişenin hafif düzeyde ve ilişkili olduğu bulunmuştur. Cinsiyet ve yaş hastanede yatan çocuklarda psikososyal semptomları, çocukların okula başlama durumu ve hastalık süresi ise annelerinin endişe düzeyini etkilemiş̧ir. Hastanede yatan çocuklar ve annelerinin yaşadıkları psikososyal sorunlar bakımından birlikte değerlendirildiği araştırmaların yapılması önerilmektedir.

Anahtar Sözcükler: Çocuk Hasta, Psikososyal Semptom, Endişe, Hastaneye Yatma.

\section{Abstract \\ Examining the Relationship between Psychosocial Symptoms in Hospitalized Children and the Anxiety Levels of Their Mothers}

Background: Hospitalization affects both children and their mothers psychosocially. Early detection of psychosocial symptoms in children and anxiety in their mothers is very important for nurses to plan and implement the necessary interventions for these problems. Objectives: The aim of the study is to define psychosocial symptoms in hospitalized children between the ages of 6-12 and the concerns of mothers and also to examine the relationship between them. Methods: This descriptive-relationship seeking research was done in a training and research hospital between July and December 2019. The sample of the study consisted of 120 children in the 6-12 age group and their mothers. The datas were obtained using the "Personal Information Form”, “Assessment Scale for Psychosocial Symptoms in Hospitalized Children”, "Parent Anxiety Resources Scale” and were evaluated using the descriptive statistics, the Mann Whitney U, the Kruskal Wallis H and the Spearman correlation tests. Results: $62.5 \%$ of the 6-12 age group hospitalized children are male, $68.3 \%$ of them have been in the hospital for less than 7 days and 58.3\% of them have had more than one hospitalization experience. Anger and Aggression levels of hospitalized boys were found to be higher. The anxiety level of the mothers of the children have not started school yet and whose illness continued for 7-15 days was found to be higher. A weakly positive and significant correlation was found between the total score of parent anxiety resources and psychosocial symptoms in hospitalized children, and a weakly negative relationship between the age of the children and the psychosocial symptoms and the anxiety levels of their mothers. Conclusion: Psychosocial symptoms in hospitalized children and anxiety in their mothers were found to be mildly and correlated. Gender and age affected the psychosocial symptoms in hospitalized children, and their mothers' level of anxiety, on the other hand, as they start school and the duration of illness. It is recommended to conduct studies in which children and their mothers in hospital are evaluated together in terms of psychosocial problems they experience.

Key Words: Child Patient, Psychosocial Symptom, Anxiety, Hospitalization.

Geliş Tarihi / Received: 28.11.2020 Kabul Tarihi / Accepted: 31.05.2021

Correspondence Author: Gonca ÜSTÜN, Dr. Öğr. Üyesi, Amasya Üniversitesi, Sağlık Bilimleri Fakültesi, Hemşirelik Bölümü, Psikiyatri Hemşireliği Anabilim Dalı, Amasya, Türkiye. Telefon: +90(358)2181767/4787 E-posta: gonca_ustun@hotmail.com

Cite This Article: Üstün G, Akan B, Küçük L. Hastanede Yatan Çocuklarda Psikososyal Semptomlar ile Annelerinin Endişe Düzeyleri Arasındaki İlişkinin İncelenmesi. Dokuz Eylül Üniversitesi Hemşirelik Fakültesi Elektronik Dergisi. 2021; 14(3): 207- 216 
$\mathbf{H}$ astaneye yatırılmanın her yaş grubu çocuk için travmatik ve stresli bir deneyim olduğu bilinmektedir (1-5). Kriz olarak nitelendirilen bu yaşantı karşısında savunmasız olan çocuk, hastalığın getirdiği fiziksel sorunların yanı sıra çeşitli psikososyal sorunları da beraberinde yaşamaktadır (6-10). Çocuk için alışılmadık bir durum olan hastaneye yatma; aile yaşamları, sosyal çevreleri, günlük rutin aktiviteleri ve alışkanlıklarından ayrı kalmalarına neden olmaktadır $(2,3,11)$. Hastaneye yatma ile birlikte kendilerini diğerlerinden farklı olarak algılayan çocuklar, yetersizlik duyguları yaşamakta ve kendilerini engellenmiş hissetmektedirler $(4,12)$. Özellikle okul çağındaki 6-12 yaş grubu çocuk için hastaneye yatma; bakımları sırasında yardıma gereksinim duymaları nedeniyle bağımlı olma, birçok faaliyetlerinden yoksun kalma ve endişelerle dolu farklı bir yaşantı anlamına gelmektedir. Giderek artan bağımlı rolleri nedeniyle çocukların çoğu kontrol kaybı yaşamakta ve hastanede zorunlu oldukları bu role karşı öfke duyabilmektedirler (7). Aynı zamanda tanımadıkları sağlık personeli ile karşılaşmak ve bilinmeyen tedavi uygulamalarına maruz kalmak çocukta kaygı ve korkuya neden olmaktadır (3,8-10). Yapılan çalışmalarda da hastanede yatmaya karşı çocukların korku, üzüntü, umutsuzluk, ilgisizlik, içe kapanma, yalnızlık, güçsüzlük ve kontrol kaybı, güvensizlik, öfke, suçluluk ve yetersizlik duygusu yaşadıkları bildirilmiştir $(5,12-14)$. Hastalık ve hastanede yatmaya bağlı olarak yaşanan bu fiziksel ve duygusal zorlantıların çocukta anksiyete ve depresyon gibi psikiyatrik sorunları ortaya çıkardığı belirtilmektedir $(7,12,15)$.

Hastanede yatmaya bağlı olarak çocuklar çeşitli faktörlerden etkilenmekte buna bağlı olarak kısa ve uzun vadeli psikososyal sorunlar yaşayabilmektedirler $(8,11,12)$. Özellikle tekrarlayan ve uzun süreli yatışlarda çocuklarda uyku bozuklukları, ayrılık kaygısı, daha düşük gelişim aşamalarına gerileme (regresyon), hiperaktivite ve saldırgan davranışlar görülebilmektedir (5). Çocuğun hastalık süresi ve hastaneye yatma ile ilgili önceki deneyimlerinin, hastalığa ve hastaneye yatmaya karşı tepkilerini etkilediği belirtilmektedir $(7,10,11)$. Bunun dışında çocuğun bazı sosyodemografik özelliklerinin de bu durumu etkileyebileceği bildirilmekte ve yapılan bir çalışmada psikososyal sorunların çocuğun cinsiyeti ve yaşı ile ilişkili olduğu ifade edilmektedir (13). Çocukların hastalık ve hastanede yatma sürecine destek olan ebeveynin varlığı da çocuk için önemli bir kaynak olarak görülmekte $(8,16)$ ancak bu konuda çocuk ile ebeveyni birlikte ele alan lisansüstü tez çalışmalarının yanı sıra sinırlı sayıda araştırma makalesi bulunmaktadır $(6,17)$.

Çocukların hastaneye yatırılması tüm aile üyelerini etkilediği gibi özellikle de anne için oldukça zor bir süreçtir $(2,16,18)$. Çocuklarının sağlığının geliştirilmesi ve sürdürülmesinde doğrudan bakıma dâhil olan annelerin psikososyal işlevselliği, çocukların fiziksel ve ruhsal sağlık sonuçları için önemli olup hastanede yatan çocuğun bakım gereksinimlerini karşılamada etkilidir (19-21). Yapılan çalışmalarda günlük yaşamı kısıtlayan, çocuğun bakım ihtiyacını arttıran ve beklenmedik bir dizi değişiklikleri de beraberinde getiren bu durumun annenin ciddi derecede korku, endişe, çaresizlik, uyku sorunları, sinirlilik ve stres yaşamasına neden olduğu ve annede anksiyete ve depresyon belirtilerinin görüldüğü bildirilmiştir (19-23). Bu zorluklarla birlikte çocuğun hastaneye yatmasıyla ilişkili olarak anneler; evdeki diğer çocukların bakımı, çalışma yaşamını sürdürme, ekonomik güçlükler, sosyal izolasyon ve evlilik ilişkilerinde yaşanan gerginlikler gibi stresörlere maruz kalmaktadırlar $(21,24)$. Genç yaşta olma, düşük eğitim seviyesi, ölümcül bir hastalığa sahip olma ve sosyal destek sistemleri gibi ebeveyn ile ilgili faktörlerin yanı sıra çocuğun yaşı, akut veya kronik hastalığa sahip olması, hastalığın süresi ve hastanede kalınan gün sayısı gibi çocuğa ilişkin değişkenlerin de annenin anksiyete ve depresyon düzeyini etkilediği belirtilmektedir (1925).

Hastanede yatan çocukların ve tüm ebeveynlerin psikolojik zorlanma belirtileri açısından risk altında olduğu ve bu süreçte çocuğun bakımından sorumlu tüm sağlık ekibinin, özellikle de çocuğa bakım veren hemşirenin önemli bir role sahip olduğu bilinmektedir $(10,18,21)$. Hemşireler, çocukların hastaneye yatış sırasındaki deneyim ve duygularını tanılayarak; hastaneye yatırılmanın çocuklar üzerindeki psikososyal etkisini azaltmakta, çocukların ve ailelerinin kendilerini yeni ortama uyum sağlamaları için yardımcı olmaktadırlar $(6,11)$. Ancak bu uyumu sağlayacak uygulamaların yetersiz olduğu, daha çok tanı ve tedavi sürecine odaklanıldığı ve bu süreci etkileyen psikososyal sorunların göz ardı edildiği bilinmektedir (10). Bununla birlikte çocuklarda görülen psikososyal semptomların ve annelerinde görülen endişenin erken dönemde saptanması, hemşirelerin bu sorunlara yönelik gerekli müdahaleleri planlaması ve uygulaması için oldukça önem taşımaktadır $(13,20)$. Literatürde geniş bir alana sahip olan bu konu hakkında özellikle anne ve çocuğu birlikte ele alan sınırlı sayıda araştırma sonuçlarına rastlanmaktadır $(6,17)$. Bu konuda ülkemizde yapılan çalışmalar çoğunlukla çocuklarda hastanede yatmaya bağglı gelişen sorunları $(10,13,26)$ ve çocuğu hastanede yatan annelerinin yaşadığı güçlükleri $(22,23,25)$ ele alan tanımlayıcı nitelikteki çalışmalardır. Bu doğrultuda çocuk ve annenin sorunlarını birlikte tanılamaya yönelik çalışmaların yapılmasına ihtiyaç duyulmaktadır. Bu araştırmanın amacı, hastanede yatan 6-12 yaş grubu çocuklarda psikososyal semptomlar ve annelerinin endişelerini tanımlamak ve aralarındaki ilişsiyi incelemektir. Bu araştırma ile aşağıdaki sorulara yanıt aranmıştır;

- Hastanede yatan çocuklarda görülen psikososyal semptomlar nelerdir?

- Hastanede yatan çocuklarda görülen psikososyal semptomları etkileyen faktörler nelerdir?

- Hastanede yatan çocukların annelerinde görülen endişe düzeyi nedir?

- Hastanede yatan çocukların annelerinde görülen endişe düzeylerini etkileyen faktörler nelerdir?

- Hastanede yatan çocuklarda görülen psikososyal semptomlarla annelerinde görülen endişe düzeyleri arasında anlamlı bir ilişki var mıdır?

\section{Yöntem}

\section{Araştırmanın Tipi}

$\mathrm{Bu}$ araştırma tanımlayıcı-ilişki arayıcı araştırma desenindedir.

\section{Araştırmanın Yapıldı̆̆ Yer}

Araştırma, Türkiye'nin Karadeniz Bölgesi'nde yer alan bir Eğitim ve Araştırma Hastanesi'nde, Temmuz-Aralık 2019 tarihleri arasında gerçekleştirilmiştir. 


\section{Araştırmanın Evreni/Örneklemi}

Araştırmanın evrenini bir eğitim ve araştırma hastanesinde yatan 6-12 yaş grubu çocuklar $(\mathrm{n}=120)$ ve anneleri $(\mathrm{n}=120)$ oluşturmuştur. Araştırmanın örneklemine akut veya kronik bir hastalık tanısı almış, en az üç gündür hastanede yatan, 6-12 yaş grubundaki çocuklar ve çocuğun yanında kalan, çalışmaya katılmayı kabul eden anneleri dahil edilmiştir. Çocuk veya annenin herhangi bir psikiyatrik hastalık tanısı olması ve annenin üvey olması araştırmanın dışlama kriterlerini oluşturmuştur.

Araştırmanın örneklem sayısı belirlenirken hastaneye önceki yıl yatan 6-12 yaş, en az üç gün hastanede yatan çocuk sayısına bakılmıştır. 2018 yılının ilk yarısında bu kriterlere uygun 132 çocuk, ikinci yarısında ise 141 çocuk hasta olduğu belirlenmiştir. 2019 yılının ikinci yarısı uygulanan bu araştırma için örneklem sayısı \%95 güven aralığı ile en az 103 olarak hesaplanmıştır. Araştırmaya altı ay süreyle devam edilmiş ve 136 çocuk hasta ve annesine ulaşılmıştır. Araştırmaya vakit ayırmak istemeyen ve bu nedenle katılmayı reddeden 16 çocuk hasta ve annesi örnekleme alınamamıştır. Altı ayın sonunda toplam 120 çocuk hasta ve annesi ile araştırma tamamlanmıştır.

\section{Veri Toplama Araçlart}

Verilerin toplanmasında çocuk ve annesi için hazırlanan "Kişisel Bilgi Formu”, "Hastanede Yatan Çocuklarda Psikososyal Semptomları Tanılama Ölçeği” ve "Ebeveynlerin Endişe Kaynakları Ölçeğì” kullanılmıştır.

\section{Kișisel Bilgi Formu}

Araştırmacılar tarafından ve anneden alınacak bilgilere dayalı olarak hazırlanan anket formu, çocuk ve annesi hakkında demografik verileri ve çocuğun hastalık özelliklerini içeren toplam 10 sorudan oluşmaktadır. Sorular oluşturulmadan önce literatür taraması yapılmış ve konu ile ilgili benzer tez çalışmaları ile araştırma makalelerinden yararlanılmıştır (10,13,14,2227).

\section{Hastanede Yatan Çocuklarda Psikososyal Semptomları Tanılama Ölçeği (ÇPSTÖ)}

Hastanede yatan 6-12 yaş grubu çocuklar için psikososyal semptomları tanılama amacıyla oluşturulmuş gözleme dayalı bir ölçektir. Üstün ve Kelleci (2013) tarafından geliştirilmiş, geçerlik ve güvenirliği saptanmıştır. Madde sayısı 24 olan 3 'lü likert tipi ölçekte yer alan her bir ifade "hiçbir zaman", "bazen" ve "sık sık" şeklinde değerlendirilip, sırasıyla 0, 1 ve 2 şeklinde puanlanmıştır. Ölçekten elde edilecek en yüksek puan " 48 ", en düşük puan ise " 0 ” dır. Ölçek toplam puanının yüksek olması klinikte yatan çocuğun psikososyal sorunlarının olduğunu belirtmektedir. Anksiyete (1, 2, 6, 10, 12, 15, 23. maddeler; 14 puan), Umutsuzluk (3, 4, 5, 9, 16. maddeler; 10 puan), İletişim Güçlüğü (14, 17, 20, 21. maddeler; 8 puan), Öfke ve Saldırganlık (7, 13, 19, 22, 24. maddeler; 10 puan), Regresyon (8, 11, 18. maddeler; 6 puan) altboyutlarından oluşmaktadır. Ölçeğin Cronbach alfa katsayısı .90 olarak belirlenmiştir (14). Bu çalışmada da ölçeğin Cronbach alfa katsayısı .90 olarak bulunmuştur.

Ebeveynlerin Endişe Kaynakları Ölçeği (EEKÖ)

Ebeveynlerin çocuklarının hastalık ve hastaneye yatma gibi durumlarında yaşadıkları endişe kaynaklarını belirleyen bir öz bildirim ölçeğidir. Gönener ve Pek (2009) tarafından geliştirilen ölçeğin geçerlik ve güvenirlik analizinde Cronbach alfa katsayısı .94 olarak belirlenmiştir. Faktör analizi yapılarak geliştirilen ölçekteki maddeler kendi içinde altı faktör altında toplanmıştır. Faktörler; "Ebeveynin çocuklarıyla, aileleriyle, çevresiyle ilgili endişe kaynakları", "Çocukta oluşturabileceği fiziksel sorunlara yönelik endişe kaynakları", "Ebeveynlerin eşleriyle aralarında oluşabilecek sorunlarla ilgili endişe kaynakları", "Hastalık dışında hastane ile ilgili endişe kaynakları", "Çocuğun dişa yönelik tepkileriyle ilgili endişe kaynakları", "Çocuğun bedenine yönelik endişe kaynakları" olarak belirlenmiştir. 57 maddeden oluşan 4'lü likert türündeki ölçekte yer alan her bir ifade "hiç düşünmem”, “çok az düşünürüm”, "biraz düşünürüm”, “çok düşünürüm” şeklinde değerlendirilip; sırasıyla 0, 1, 2 ve 3 şeklinde puanlanmıştır. Ölçekten alınan toplam puanların yüksekliği, yaşanan endişe düzeyinin arttığını göstermektedir (27). Bu çalışmada ölçeğin Cronbach alfa katsayısı .96 olarak bulunmuştur.

\section{Verilerin Toplanmast}

Temmuz-Aralık 2019 tarihleri arasında hastanenin genel çocuk kliniklerinde yatan çocuk hastaların yanında kalan anneleri ile görüşmeler en az üç gün çocuğu takip eden tek araştırmacı hemşire (ikinci yazar) tarafından yapılmıştır. Yüzyüze görüşmeler hasta odasında, hastaneye yatışın üçüncü veya dördüncü gününde gerçekleştirilmiştir. Kişisel Bilgi Formu görüşme sırasında anneden alınan bilgiler doğrultusunda hemşire tarafından, EEKÖ ise çocuğun annesi tarafindan doldurulmuştur. Araştırmacı hemşire araştırmanın yapıldığı iki klinik (Çocuk Servisi ve Çocuk Cerrahi Servisi) arasında dönüşümlü olarak 4'er saat (haftasonları da dahil haftanın 4-5 günü) çalışarak çocukları gözlemlemiştir. Gözlemler çocuğun rutin bakım ve tedavi uygulamaları sırasında gerçekleştirilmiştir. Araştırmacı hemşire, çocuğun bakımına doğrudan katılmış ve üç gün boyunca takip ettiği çocuk için ÇPSTÖ’yü doldurmuştur. Üçüncü günü yetersiz gözlemlediği veya yoğunluk nedeniyle değerlendiremediği çocuklar için dördüncü günü tekrar izlem yaparak ölçeği tamamlamıştır.

\section{Araştırmanın Değişkenleri}

Araştırmanın bağımlı değişkenleri; çocukların psikososyal semptomları ve annelerinin endişe düzeyleridir. Araştırmanın bağımsız değişkenleri ise kişisel bilgi formunda yer alan çocuğun cinsiyet, eğitim durumu ve hastalığa ilişkin verileri ile annelerinin yaş, çocuk sayısı, eğitim, çalışma ve hastalık durumlarıdır.

\section{Verilerin Değerlendirilmesi}

$\mathrm{Bu}$ araştırmada elde edilen veriler IBM SPSS Statistics Version 25 paket programı ile analiz edilmiştir. Araştırma verilerinin sınıflanması ve özelliklerinin açıklanması için tanımlayıcı istatistikler yapılmıştır. Araştırmada kullanılan ölçeklerin normal dağılım özellikleri Kolmogorov Smirnov testi ile incelenmiştir. ÇPSTÖ $(Z=.097 ; p=.007)$ ve EEKÖ’nün $(Z=.169 ; p=.000)$ her ikisinin de normal dağılım göstermediği saptanmıştır. Değişkenler normal dağılmadığı için iki grup karşılaştırmalarında Mann Whitney U testi, üç ve daha fazla grup karşılaştırmalarında Kruskal Wallis H testi kullanılmıştır. İkiden fazla gruplar arasında fark anlamlı olduğunda farkın hangi gruptan kaynaklandığını tespit etmek için Bonferroni düzeltmesi ile çoklu karşılaştırma yapılmıştır. Sonuçlar yorumlanırken anlamlılık düzeyi olarak .05 kullanılmış ve $\mathrm{p}<.05$ olması durumunda anlamlı bir farklılı̆̆ın olduğu, $\mathrm{p}>.05$ olması durumunda ise anlamlı bir farklılığın olmadığı belirtilmiştir. ÇPSTÖ ve EEKÖ arasındaki ilişkiyi belirlemek için normal dağılım varsayımı karşılanmadığından Spearman korelasyon analizi yapılmıştır. 


\section{Araştırmanın Etik Yönü}

Ölçek kullanımı için yazardan elektronik posta yolu ile izin alınmıştır. Araştırmaya başlamadan önce araştırmanın yapıldı̆̆ 1 ilin Sağlık Müdürlüğü (25.04.2019 tarihli 3814 sayılı karar) ve bir üniversitenin Girişimsel Olmayan Klinik Araştırmalar Etik Kurulu'ndan (20.06.2019 tarihli 33 sayılı karar) yazılı izin alınmıştır. Çocuk hastanın annesinden bilgilendirilmiş onam alınmıştır. Makalede araştırma ve yayın etiğine uyulmuştur.

\section{Bulgular}

Hastanede yatan 6-12 yaş grubu çocukların yaş ortalaması 8.39 $\pm 2.18, \% 62.5$ 'i erkek, \%86.7'si akut hastalık tanısı ile \%68.3'ü 7 günden daha kısa süredir hastanede yatıyor ve \%58.3'ü birden fazla hastanede yatma deneyimi yaşamıştır (Tablo 1). Çocukların annelerinin \%45’i 24-34 yaş arasında, \%39.2'si ilkokul mezunu, \%79.2'si çalışmıyor, \%46.7'si iki çocuk sahibidir (Tablo 1).

Tablo 1. Araştırma Kapsamına Alınan Çocukların ve Annelerinin Demografik ve Hastalık Özelliklerine Göre Dağılımları

\begin{tabular}{|c|c|c|c|}
\hline Çocukların Özellikleri & & Ort. \pm SS. & Min.-Mak. \\
\hline \multirow[t]{2}{*}{ Yaş } & & $8.39 \pm 2.18$ & $6-12$ \\
\hline & & $\mathbf{n}$ & $\%$ \\
\hline \multirow{2}{*}{ Cinsiyet } & $\mathrm{K} 1 \mathrm{z}$ & 45 & 37.5 \\
\hline & Erkek & 75 & 62.5 \\
\hline \multirow{3}{*}{ Eğitim durumu } & Okula başlamamış & 13 & 10.8 \\
\hline & Anaokulu/Kreş & 12 & 10.0 \\
\hline & İlkokul & 95 & 79.2 \\
\hline \multirow{2}{*}{ Hastalığın tanısı } & Akut & 104 & 86.7 \\
\hline & Kronik & 16 & 13.3 \\
\hline \multirow{3}{*}{ Hastalığın süresi } & 7 günden az & 82 & 68.3 \\
\hline & 7-15 gün & 26 & 21.7 \\
\hline & 15 günden fazla & 12 & 10.0 \\
\hline \multirow{2}{*}{ Hastane deneyimi } & İlk kez & 50 & 41.7 \\
\hline & 2 veya daha fazla & 70 & 58.3 \\
\hline \multicolumn{4}{|l|}{ Annelerin Özellikleri } \\
\hline \multirow{3}{*}{ Yaş } & 24-34 yaş & 54 & 45.0 \\
\hline & 35-44 yaş & 52 & 43.3 \\
\hline & 45 yaş ve üzeri & 14 & 11.7 \\
\hline \multirow{5}{*}{ Eğitim durumu } & Okur-yazar & 5 & 4.2 \\
\hline & İlkokul & 47 & 39.2 \\
\hline & Ortaokul & 20 & 16.7 \\
\hline & Lise & 36 & 30.0 \\
\hline & Üniversite & 12 & 10.0 \\
\hline \multirow{2}{*}{ Çalışma durumu } & Çalışıyor & 25 & 20.8 \\
\hline & Çalışmiyor & 95 & 79.2 \\
\hline \multirow{4}{*}{ Çocuk sayısı } & 1 & 14 & 11.7 \\
\hline & 2 & 56 & 46.7 \\
\hline & 3 & 39 & 32.5 \\
\hline & 4 ve üzeri & 11 & 9.2 \\
\hline \multirow{2}{*}{ Fiziksel hastalık durumu } & Evet & 26 & 21.7 \\
\hline & Hayır & 94 & 78.3 \\
\hline Toplam & & 120 & 100 \\
\hline
\end{tabular}

*n: Örneklem sayısı, Ort: Ortalama, SS: Standart sapma, Min-Mak: Mininum-Maksimum değerler

Çocukların ÇPSTÖ toplam puanı ve alt boyut puanları ile annelerinin EEKÖ toplam puan ortalamaları Tablo 2'de verilmiştir. Ölçeklerden alınabilecek en yüksek puan ile karşılaştırıldığında hastanede yatan çocuklarda psikososyal semptomların ve annelerinde görülen endișenin hafif düzeyde olduğu bulunmuştur (Tablo 2). 
Tablo 2. ÇPSTÖ ve Alt Boyutlart ile EEKÖ Toplam Puan Ortalamalart

\begin{tabular}{lcc}
\hline Ölçekler ve Alt Boyutları & Ort. \pm SS. & Min.-Mak. \\
\hline ÇPSTÖ & $16.65 \pm 9.13$ & $1-41$ \\
\hline Anksiyete & $5.10 \pm 3.51$ & $0-14$ \\
\hline Umutsuzluk & $4.05 \pm 2.17$ & $0-10$ \\
\hline İletişim Güçlüğ̈̈ & $1.86 \pm 1.80$ & $0-8$ \\
\hline Öfke ve Saldırganlık & $2.60 \pm 2.25$ & $0-10$ \\
\hline Regresyon & $3.03 \pm 1.70$ & $0-6$ \\
\hline EEKÖ & $39.64 \pm 34.27$ & $0-156$ \\
\hline
\end{tabular}

*Ort: Ortalama, SS: Standart sapma, Min-Mak: Mininum-Maksimum değerler

Çocukların demografik değişkenler ve hastalık özellikleri açısından ÇPSTÖ toplam puanı, ÇPSTÖ alt boyutları ve annelerinin EEKÖ toplam puan ortalamaları ve anlamlılık düzeyleri Tablo 3'de verilmiştir. Cinsiyetleri açısından bakıldı̆̆ında erkek çocuklarının Öfke ve Saldırganlık alt boyut puanı kız çocuklarına göre anlamlı düzeyde yüksek bulunmuştur (p $<.05$, Tablo 3). Hastanede yatan çocukların annelerinin endişe düzeylerine bakıldığında çocukların okula başlama durumları ve hastalık süresine göre anlamlı düzeyde fark bulunmuştur $(\mathrm{p}<.05$, Tablo 3$)$. Çocuğu henüz okula başlamamış annelerin endişe düzeyi çocuğu ilkokula gidenlere göre, hastalığın süresi (tıbbi tanının konulmasından itibaren geçen süre) 7-15 gün olanların 7 günden az olanlara göre anlamlı düzeyde yüksek olduğu bulunmuştur $(\mathrm{p}<.05$, Tablo 3$)$. Çocuklarda hastalığın akut ya da kronik olması ve hastanede yatma deneyimleri açısından bakıldığında ÇPSTÖ toplam puanı, ÇPSTÖ alt boyut puanları ve annelerinin EEKÖ puanları arasında anlamlı bir farklılık saptanmamıştır $(\mathrm{p}>.05$, Tablo 3$)$. 
Tablo 3. Çocukların Demografik Değişsenler ve Hastalık Özellikleri Açısından ÇPSTÖ Puan Ortalamaları ve Annelerinin EEKÖ Puan Ortalamalarının Karşılaştırılması

\begin{tabular}{|c|c|c|c|c|c|c|c|c|c|c|c|c|c|c|c|}
\hline \multirow[b]{2}{*}{ Değişkenleı } & & \multicolumn{2}{|l|}{ ÇPSTÖ } & \multicolumn{2}{|l|}{ Anksiyete } & \multicolumn{2}{|c|}{ Umutsuzluk } & \multicolumn{2}{|c|}{$\begin{array}{r}\text { İletişim } \\
\text { Güçlüğüu }\end{array}$} & \multicolumn{2}{|c|}{$\begin{array}{c}\text { Öfke ve } \\
\text { Saldırganlık }\end{array}$} & \multicolumn{2}{|c|}{ Regresyon } & \multicolumn{2}{|c|}{ EEKÖ } \\
\hline & & Ort. \pm SS. & $\begin{array}{l}\text { Sira } \\
\text { Ort. }\end{array}$ & Ort. \pm SS. & $\begin{array}{l}\text { Sura } \\
\text { Ort. }\end{array}$ & Ort. \pm SS. & $\begin{array}{l}\text { Sira } \\
\text { Ort. }\end{array}$ & Ort. \pm SS. & $\begin{array}{l}\text { Sira } \\
\text { Ort. }\end{array}$ & Ort. \pm SS. & $\begin{array}{l}\text { Sira } \\
\text { Ort. }\end{array}$ & Ort. \pm SS. & $\begin{array}{l}\text { Sira } \\
\text { Ort. }\end{array}$ & Ort. \pm SS. & Sira Ort. \\
\hline \multirow{3}{*}{ Cinsiyet } & $\mathrm{K}_{1 \mathrm{z}}$ & $15.73 \pm 9.11$ & 57.12 & $4.77 \pm 3.23$ & 58.00 & $4.17 \pm 2.29$ & 61.68 & $1.53 \pm 1.80$ & 52.94 & $2.15 \pm 2.43$ & 51.59 & $3.08 \pm 1.62$ & 61.98 & $39.35 \pm 31.28$ & 62.64 \\
\hline & Erkek & $17.21 \pm 9.15$ & 62.53 & $5.30 \pm 3.68$ & 62.00 & $3.97 \pm 2.11$ & 59.79 & $2.06 \pm 1.78$ & 65.03 & $2.86 \pm 2.11$ & 65.85 & $3.00 \pm 1.76$ & 59.61 & $39.81 \pm 36.15$ & 59.21 \\
\hline & & $\begin{array}{c}Z=-.825 \\
p=.410\end{array}$ & & $\begin{array}{c}Z=-.613 \\
p=.540\end{array}$ & & $\begin{aligned} Z & =-.291 \\
p & =.771\end{aligned}$ & & $\begin{array}{c}Z=-1.886 \\
p=.059\end{array}$ & & $\begin{array}{c}Z=-2.204 \\
\mathbf{p}=\mathbf{. 0 2 8}\end{array}$ & & $\begin{array}{c}Z=-.366 \\
p=.715\end{array}$ & & $\begin{array}{l}Z=-.523 \\
p=.601\end{array}$ & \\
\hline \multirow{4}{*}{$\begin{array}{l}\text { Ĕgitim } \\
\text { durumu }\end{array}$} & Okula başlamamış & $15.84 \pm 8.00$ & 57.58 & $4.69 \pm 2.98$ & 58.04 & $4.15 \pm 2.30$ & 62.23 & $1.38 \pm 1.32$ & 53.31 & $2.53 \pm 2.81$ & 56.35 & $3.07 \pm 1.55$ & 59.35 & $68.84 \pm 40.66$ & 82.42 \\
\hline & Anaokulu/Kreş & $19.66 \pm 6.44$ & 77.08 & $6.25 \pm 2.80$ & 76.25 & $4.25 \pm 1.60$ & 65.83 & $2.41 \pm 1.56$ & 73.92 & $3.25 \pm 1.81$ & 73.33 & $3.50 \pm 1.88$ & 70.46 & $44.83 \pm 42.41$ & 63.38 \\
\hline & İlkokul & $16.38 \pm 9.55$ & 58.81 & $5.02 \pm 3.66$ & 58.85 & $4.01 \pm 2.23$ & 59.59 & $1.86 \pm 1.88$ & 59.79 & $2.52 \pm 2.23$ & 59.45 & $2.96 \pm 1.71$ & 59.40 & $35.67 \pm 31.07$ & 57.14 \\
\hline & & $\begin{array}{c}\chi^{2}=3.050 \\
p=.218\end{array}$ & & $\begin{array}{c}\chi^{2}=2.767 \\
p=.251\end{array}$ & & $\begin{array}{l}\chi^{2}=.388 \\
p=.824\end{array}$ & & $\begin{array}{c}\chi^{2}=2.493 \\
p=.287\end{array}$ & & $\begin{array}{c}\chi^{2}=1.960 \\
p=.375\end{array}$ & & $\begin{array}{l}\chi^{2}=1.125 \\
p=.570\end{array}$ & & $\begin{array}{l}\chi^{2}=6.136 \\
\mathbf{p}=\mathbf{. 0 4 7}(3<1)\end{array}$ & \\
\hline \multirow{3}{*}{$\begin{array}{l}\text { Hastalığın } \\
\text { tanısı }\end{array}$} & Akut & $16.74 \pm 9.43$ & 60.52 & $5.19 \pm 3.62$ & 61.00 & $4.06 \pm 2.26$ & 60.31 & $1.87 \pm 1.76$ & 61.03 & $2.59 \pm 2.30$ & 60.14 & $3.00 \pm 1.72$ & 60.24 & $39.99 \pm 35.20$ & 60.60 \\
\hline & Kronik & $16.12 \pm 7.09$ & 60.38 & $4.56 \pm 2.78$ & 57.25 & $3.93 \pm 1.52$ & 61.75 & $1.81 \pm 2.10$ & 57.06 & $2.62 \pm 1.99$ & 62.81 & $3.18 \pm 1.64$ & 62.19 & $37.37 \pm 28.38$ & 59.88 \\
\hline & & $\begin{array}{c}Z=-.015 \\
p=.988\end{array}$ & & $\begin{array}{c}Z=-.403 \\
p=.687\end{array}$ & & $\begin{array}{l}Z=-.156 \\
p=.876\end{array}$ & & $\begin{array}{c}Z=-.435 \\
p=.664\end{array}$ & & $\begin{array}{c}Z=-.290 \\
p=.772\end{array}$ & & $\begin{array}{l}Z=-.211 \\
p=.833\end{array}$ & & $\begin{array}{l}Z=-.077 \\
p=.938\end{array}$ & \\
\hline \multirow{4}{*}{$\begin{array}{l}\text { Hastalığın } \\
\text { süresi }\end{array}$} & 7 günden az & $15.76 \pm 8.78$ & 57.27 & $4.80 \pm 3.39$ & 57.61 & $3.92 \pm 2.29$ & 58.41 & $1.79 \pm 1.69$ & 59.65 & $2.35 \pm 2.12$ & 57.01 & $2.89 \pm 1.76$ & 57.63 & $32.37 \pm 27.70$ & 53.94 \\
\hline & 7-15 gün & $18.73 \pm 10.40$ & 66.98 & $6.15 \pm 4.01$ & 69.77 & $4.26 \pm 1.86$ & 64.12 & $1.73 \pm 2.12$ & 55.27 & $3.30 \pm 2.54$ & 70.15 & $3.26 \pm 1.53$ & 65.29 & $60.34 \pm 43.65$ & 78.87 \\
\hline & 15 günden fazla & $18.25 \pm 8.28$ & 68.50 & $4.91 \pm 2.99$ & 60.17 & $4.41 \pm 2.06$ & 66.92 & $2.66 \pm 1.72$ & 77.63 & $2.75 \pm 2.30$ & 63.42 & $3.50 \pm 1.62$ & 69.71 & $44.41 \pm 35.99$ & 65.54 \\
\hline & & $\begin{array}{c}\chi^{2}=2.246 \\
p=.325\end{array}$ & & $\begin{array}{c}\chi^{2}=2.437 \\
p=.296\end{array}$ & & $\begin{aligned} \chi^{2} & =1.006 \\
p & =.605\end{aligned}$ & & $\begin{aligned} \chi^{2} & =3.713 \\
p & =.156\end{aligned}$ & & $\begin{array}{c}\chi^{2}=2.994 \\
p=.224\end{array}$ & & $\begin{array}{l}\chi^{2}=1.945 \\
p=.378\end{array}$ & & $\begin{array}{l}\chi^{2}=10.421 \\
\mathbf{p}=\mathbf{. 0 0 5}(1<2)\end{array}$ & \\
\hline \multirow{3}{*}{$\begin{array}{l}\text { Hastane } \\
\text { deneyimi }\end{array}$} & İlk kez & $17.22 \pm 9.43$ & 62.91 & $5.28 \pm 3.90$ & 60.60 & $4.28 \pm 2.08$ & 64.34 & $1.98 \pm 1.90$ & 62.25 & $2.62 \pm 2.14$ & 61.24 & $3.06 \pm 1.59$ & 61.32 & $36.18 \pm 30.19$ & 59.04 \\
\hline & 2 ve daha fazla & $16.25 \pm 8.95$ & 58.78 & $4.98 \pm 3.24$ & 60.43 & $3.88 \pm 2.24$ & 57.76 & $1.78 \pm 1.74$ & 59.25 & $2.58 \pm 2.34$ & 59.97 & $3.01 \pm 1.78$ & 59.91 & $42.11 \pm 36.93$ & 61.54 \\
\hline & & $\begin{array}{c}\mathrm{Z}=-.642 \\
\mathrm{p}=.521\end{array}$ & & $\begin{array}{c}\mathrm{Z}=-.027 \\
\mathrm{p}=.979\end{array}$ & & $\begin{array}{c}\mathrm{Z}=-1.034 \\
\mathrm{p}=.301\end{array}$ & & $\begin{array}{c}\mathrm{Z}=-.477 \\
\mathrm{p}=.634\end{array}$ & & $\begin{array}{c}\mathrm{Z}=-.200 \\
\mathrm{p}=.842\end{array}$ & & $\begin{array}{l}\mathrm{Z}=-.221 \\
\mathrm{p}=.825\end{array}$ & & $\begin{array}{l}Z=-.389 \\
p=.698\end{array}$ & \\
\hline
\end{tabular}

* Ort: Ortalama, SS: Standart sapma, $\chi^{2}$ : Kruskal Wallis H testi, Z: Mann Whitney U testi, p: Anlaml1l1k düzeyi 
Çocukları hastanede yatan annelerin bazı değişkenler açısından EEKÖ puan ortalamaları Tablo 4'de verilmiştir. Annelerin yaş grubu, eğitim ve çalışma durumu, çocuk sayısı ve fiziksel hastalık durumları açısından endişe düzeyleri arasında anlamlı bir farklılık bulunmamıştır ( $\mathrm{p}>.05$, Tablo 4).

Tablo 4. Annelerin Bazı Değ̆işkenler Açısından EEKÖ Puan Ortalamalarının Karşılaş̧tırılması

Değişkenler

\begin{tabular}{lcc} 
& \multicolumn{2}{c}{ EEKÖ } \\
\cline { 2 - 3 } & Ort. \pm SS. & Sira Ort. \\
\hline 24-34 yaş & $47.29 \pm 39.64$ & 66.07 \\
\hline 35-44 yaş & $35.96 \pm 28.96$ & 59.46 \\
\hline 45 yaş ve üzeri & $23.78 \pm 22.10$ & 42.86 \\
\hline \multicolumn{3}{c}{$\chi^{2}=5.037, \mathrm{p}=.081$} \\
\hline Okur-yazar & $32.00 \pm 18.72$ & 56.80 \\
\hline İlkokul & $43.51 \pm 41.30$ & 60.44 \\
\hline Ortaokul & $44.10 \pm 45.97$ & 64.78 \\
\hline Lise & $37.66 \pm 28.77$ & 61.93 \\
\hline Üniversite & $26.16 \pm 15.56$ & 50.88 \\
\hline \multicolumn{2}{c}{$\chi^{2}=1.399, \mathrm{p}=.855$} \\
\hline
\end{tabular}

\begin{tabular}{|c|c|c|c|}
\hline \multirow{3}{*}{ Çalışma durumu } & Çalışıyor & $41.20 \pm 38.26$ & 61.38 \\
\hline & Çalışmıyor & $39.23 \pm 33.35$ & 60.27 \\
\hline & \multicolumn{3}{|c|}{$\mathrm{Z}=-.142, \mathrm{p}=.887$} \\
\hline \multirow{5}{*}{ Çocuk sayısı } & 1 & $42.71 \pm 39.76$ & 64.21 \\
\hline & 2 & $41.12 \pm 33.53$ & 62.76 \\
\hline & 3 & $36.25 \pm 35.51$ & 55.00 \\
\hline & 4 ve üzeri & $40.18 \pm 29.61$ & 63.77 \\
\hline & \multicolumn{3}{|c|}{$\chi^{2}=1.469, \mathrm{p}=.689$} \\
\hline \multirow{3}{*}{ Fiziksel hastalık durumu } & Evet & $36.50 \pm 34.21$ & 56.96 \\
\hline & Hayır & $40.51 \pm 34.42$ & 61.48 \\
\hline & \multicolumn{3}{|c|}{$Z=-.586, p=.558$} \\
\hline
\end{tabular}

*Ort: Ortalama, SS: Standart sapma, $\chi^{2}$ : Kruskal Wallis H testi, Z: Mann Whitney U testi, p: Anlamlılık düzeyi

Hastanede yatan çocukların psikososyal semptomları ile annelerinin yaşadıkları endişe düzeyleri ve çocukların yaşı arasındaki ilişki Tablo 5'de verilmiştir. EEKÖ ile ÇPSTÖ ve Anksiyete, Umutsuzluk, Öfke ve Saldırganlık, Regresyon alt boyutları arasında zayıf düzeyde pozitif yönlü; EEKÖ ile İletişim Güçlüğü alt boyutu arasında ise çok zayıf düzeyde pozitif yönlü anlamlı bir ilişki bulunmuştur ( $<<.05$, Tablo 5). Çocukların yaşı ile EEKÖ, ÇPSTÖ ve Anksiyete, Umutsuzluk, Öfke ve Saldırganlık, Regresyon alt boyutları arasında zayıf düzeyde negatif yönlü anlamlı bir ilişki bulunmuştur $(\mathrm{p}<.05$, Tablo 5).

Tablo 5. Çocukların ÇPSTÖ Toplam Puanı ile Annelerinin EEKÖ Toplam Puanları ve Çocukların Yaşı Arasındaki İlişki

\begin{tabular}{|c|c|c|c|c|}
\hline \multirow[t]{2}{*}{ Ölçek ve Alt Boyutları } & \multicolumn{2}{|c|}{ EEKÖ } & \multicolumn{2}{|c|}{ Çocukların yaşı } \\
\hline & $\mathbf{r}$ & $\mathbf{p}$ & $\mathbf{r}$ & $\mathbf{p}$ \\
\hline ÇPSTÖ & .45 & .000 & -.30 & .001 \\
\hline Anksiyete & .41 & .000 & -.37 & .000 \\
\hline Umutsuzluk & .27 & .003 & -.20 & .024 \\
\hline İletişim Güçlüğü & .23 & .010 & -.15 & .090 \\
\hline Öfke ve Saldırganlık & .32 & .000 & -.19 & .036 \\
\hline Regresyon & .46 & .000 & -.19 & .030 \\
\hline EEKÖ & 1.00 & . & -.20 & .029 \\
\hline
\end{tabular}

*r: Korelasyon katsayısı, p: Anlamlılık düzeyi

\section{Tartışma}

Çocuk için hoş olmayan yaşantıları içeren ve alışılmadık bir durum olarak kabul edilen hastaneye yatmanın, hem çocuk hem de aile için travmatik bir deneyim olduğu ve önemli psikolojik sorunlara yol açtığı belirtilmektedir $(2,7,11)$. Bu araştırmadan elde edilen bulgular hastanede yatmanın 6-12 yaş grubu çocuklarda hafif düzeyde psikososyal semptomlara neden olduğunu; hastanede yatan çocukların anksiyete, umutsuzluk, iletişim güçlüğü, öfke ve saldırganlık, regresyon yaşadıklarını göstermiştir. Hastaneye yatışların psikososyal etkisini değerlendiren bir çalışmada, 6-12 yaş arası hasta çocukların çoğunluğunun hafif düzeyde etkilendiği ve hastanede kalmanın kısa ve uzun vadeli etkisinin bir sonucu olarak psikososyal sorunlar yaşadığı bulunmuştur (11). 5-9 yaş arası çocukların hastaneye yatış görüşlerine ilişkin yapılan nitel bir çalışmada; çocukların yalnızlık, Dokuz Eylül Üniversitesi Hemşirelik Fakültesi Elektronik Dergisi 
korku, kızgınlık ve üzüntü hissettikleri saptanmıştır (5). 7-11 yaş arası çocuklarda hastaneye yatmanın anlamını, hastanede yatan çocukların deneyim ve davranışlarını belirlemek için yapılan bir başka nitel çalışmada; çocuklar korku, kaygı ve yalnızlık yaşadıkları, ev ortamına özlem duyduklarını ifade etmişlerdir (6). En az bir hafta hastane deneyimi yaşayan 7-12 yaş arası çocuklarda yapılan çalışmada ise çocukların korku, heyecan, utanma ve merak gibi duyguları yaşadıkları belirlenmiştir (26). Yapılan çalışmalar aynı zamanda çocukların, hastaneye yatmanın hem iyi hem de kötü sonuçlarının olduğunu bildirmekte ve hastaneye yatırılma konusundaki görüşlerinin her zaman olumsuz olmadığını göstermektedir $(5,26)$.

Hastanede yatarak tedavi gören ağır veya kronik hastalığa sahip çocuklar, ilgili prosedürler ve tekrarlı hastaneye yatışlar nedeniyle sıklıkla anksiyete yaşamakta ve normal gelişimleri üzerinde olumsuz etkilere maruz kalmaktadırlar $(1,5)$. Bu araştırmada çocukların akut veya kronik hastalığa sahip olma durumları, hastalığın süresi ve hastane deneyimleri ile yaşadıkları psikososyal semptomlar arasında anlamlı bir fark olmamakla birlikte akut hastalık nedeniyle hastanede yatan, ilk kez yatışı olan ve bir haftadan uzun süredir hastanede yatan çocuklarda psikososyal semptom puanlarının daha yüksek olduğu bulunmuştur. Literatürde bir çalışma çocukların yaşadığı psikososyal sorunların hastanede kalış sıklığı ile ilişkili olduğunu göstermiştir (11). Başka bir çalışmada; hastanede yatan ve hastalık belirtileri 15 günden daha uzun süre devam eden 6-12 yaş çocukların psikososyal açıdan riskli olduklarına vurgu yapılmıştır (10). Araştırma sonuçları çocuğun hastalık süresi ve hastaneye yatma ile ilgili önceki deneyimlerinin, hastalığa ve hastaneye yatmaya karşı tepkilerini etkilediği genel görüşünü destekler niteliktedir (7). Mevcut araştırmada akut hastalıkların aniden ortaya çıkmış olmasının daha önce hastaneye yatmamış olma ile ilişkili olarak beklenmedik durumlara yol açmış olabileceği ve hastalığın daha uzun süre devam etmesi durumunda ise hastalığın getirdiği fiziksel sorunların yanı sıra önemli psikososyal sorunların da beraberinde görülebileceği düşünülmektedir.

Araştırmada psikososyal semptomların düşük düzeyde olduğu, erkek çocukların daha fazla öfke ve saldırganlık yaşadıkları, psikososyal semptomların yaş ile negatif yönde ilişkili olduğu saptanmıştır. Hastanede çeşitli nedenlerle yatarak tedavi görmekte olan 6-12 yaş grubu çocukların psikososyal güçlüklerinin, çocukla, ailesel-çevresel ve hastalık-tedavi ile ilgili nedenlerle ilişkisini araştıran bir çalışmada küçük yaşta olma ve uzun yatış süresi psikososyal uyumun bozulması ile ilişkili bulunmuştur. Ayrıca ÇPSTÖ'nün kullanıldığı bu çalışma sonuçlarına göre kız çocukları erkeklere göre daha fazla regresyon göstermiştir (13). Aynı ölçme aracının kullanıldığı, 11-12 yaşındaki çocukların hastaneye yatmaya bağlı düşük düzeyde psikososyal semptomlar gösterdiği tespit edilen bir başka çalışmada hastanede yatış süresi arttıkça regresyonun azaldığ bulunmuştur (28). Literatürde sınırlı sonuçları olmasına karşın mevcut çalışmada cinsiyet ve yaş değişkeninin çocuklarda psikososyal semptomlar üzerinde etkili olduğu söylenebilir. Ancak bu çalışmada çocuklar hastaneye yatışlarının üç ve dördüncü günlerinde değerlendirildikleri için yatış süreleri ile psikososyal semptomlar arasındaki ilişkiye bakılamamıştır.

Çocuğu hastanede yatan annelerin endişe yaşadığını gösteren bu araştırmada özellikle hastalığın süresinin annenin endişe düzeyi üzerinde etkili olduğu ancak hastalığın akut ya da kronik olması ile annelerin endişe düzeyleri arasında anlamlılık olmadığı saptanmıştır. Yapılan bir çalışmada akut veya kronik hastalık nedeniyle hastanede yatmakta olan 7-12 yaş arası çocukların annelerinin anksiyete ve depresyon belirtileri gösterdikleri bulunmuştur (23). Pediatri kliniklerinde yapılan bir çalışmada refakatçi olarak çocuklarının yanında kalan annelerin anksiyete yaşadıkları ve anksiyete düzeyleri ile çocukta kronik hastalık varlığı, çocuğun hastalık süresi ve hastanede rekafatçi olarak kalınan gün sayısı arasında anlamlılık bulunmuştur (25). Farklı stresörlerin hastanede yatan çocukların annelerindeki etkisini araştıran bir araştırmada annelerin stres düzeyleri ile çocukların hastanede yatış sürelerinin ilişkili olduğu bulunmuştur (20). Hastanede yatan ciddi fiziksel hasarı olmayan çocuklara bakan, çoğunluğunu annelerin oluşturduğu bakıcıların akut stres algısını inceleyen bir araştırmada da yatış süresi uzadıkça bakıcıların daha yüksek düzeyde stres ve anksiyete algıladıkları saptanmıştır (19). Hastanede yatarak tedavi gören çocukların annelerinde, çeşitli tıbbi ve sosyodemografik faktörlerin anksiyete düzeyine etkisini belirlemek amacıyla yapılan çalışmada; hastalığı 30 günden daha uzun süredir devam eden çocukların annelerinde anksiyete düzeyi daha yüksek bulunmuştur (22). Bu sonuçlar doğrultusunda çocuğu hastanede yatan annelerin endişe yaşadıkları ve endişe düzeylerinin hastalık süresinden etkilendiği söylenebilir. Mevcut çalışmada annelerin endişe düzeyinin çocuğun yaşı ve okula başlama durumundan da etkilendiği görülmüştür. Çocuğu okula giden ve çocuğunun yaşı daha büyük olan annelerin endişe düzeylerinin daha düşük olması birbirini destekleyen bulgulardır. Aynı zamanda annelerin hastanede refaket ettiği çocuğu dışında evdeki çocuklarının varlığı, çalışıyor olması gibi sorumluluklarının çeşitliliği veya bazı fiziksel hastalıklara sahip olması gibi değişkenlerden de etkilenebileceği düşünülmektedir.

Araştırmada 6-12 yaş grubu çocukların psikososyal semptom puanları ile annelerinin endişe düzeyleri arasında zayıf düzeyde pozitif yönlü anlamlı bir ilişki olduğu bulunmuştur. Yaşamı boyunca anne ile çocuk arasında kurulan bağın hastanede yatıştan kaynaklanan kaygı ve korkuların hafifletilmesinde rol oynadığı özellikle de annenin hastanede bulunmasının temel amacının bakım uygulamaları sırasında çocuğun yaşadığı travmayı en aza indirmek olduğu bilinmektedir (16). En az 3 gündür hastanede yatan 7-12 yaş çocuklarda yapılan nitel bir araştırmanın sonuçları ebeveynlerin varlığının, çocukların hastanede kalışları sırasında baş etmelerinin ana kaynağı olduğunu belirtmiştir. Aynı zamanda bakımı uygulamada ebeveynlerin varlığının, hastanede yatma sırasında çocuklar üzerinde olumlu bir etkiye sahip olduğu görülmüştür (8). Literatürde hastanede yatan 9-12 yaş arasındaki günübirlik yatış yapılan çocuklarına refakat eden çoğunluğunu annelerin oluşturduğu ebeveynlerin yaşadıkları anksiyetenin, çocuklarının anksiyete düzeyine etkisini değerlendiren bir araştırmada çocukların anksiyete puanları ile ebeveynlerin anksiyete puanları arasında yüksek düzeyde pozitif yönlü anlamlı bir ilişki bulunmuştur. Bu doğrultuda ebeveynlerin anksiyetesinin çocuklarının anksiyete düzeyini doğrudan etkilediği ifade edilmiştir (17). Mevcut literatürle benzer şekilde bu araştırmadan elde edilen bulgular da hastanede yatan çocukların psikososyal semptomlar yaşaması ile annelerinin endişe düzeylerinin ilişkili olduğunu göstermiştir.

\section{Kisıtlılıklar}

Hastanede yatan 6-12 yaş grubu çocukların daha çok akut hastalık nedeniyle ve kısa süreli yatışlarının olması, bu araştırmanın bulguları değerlendirilirken göz önünde bulundurulmalıdır. Araştırma bulguları tartışılırken, hastanede yatan çocuklar ve annelerinin yaşadıkları psikososyal sorunları birlikte ele alan çalışmalar sınırlı kalmıştır. Araştırma sonuçları araştırma 
verilerinin toplandığı eğitim araştırma hastanesinde yatan çocuk hastalarla sınılıdır.

\section{Sonuçların Uygulamada Kullanımı}

Hastanede yatan çocuklarda psikososyal semptomların ve annelerinde görülen endişenin hafif düzeyde olduğu bulunmuştur. Çocukların hastanede yatmaya bağlı psikososyal semptomları ile annelerinin endişe düzeyleri arasında zayıf düzeyde pozitif yönlü, çocukların yaşı ile psikososyal semptomlar ve annelerinin endişe düzeyleri arasında zayıf düzeyde negatif yönlü anlamlı bir ilişki olduğu saptanmıştır. Cinsiyet ve yaş hastanede yatan çocuklarda psikososyal semptomları, çocukların okula başlama durumu ve hastalık süresi ise annelerinin endişe düzeyini etkilemiştir.

Psikososyal bakımın çoğu zaman göz ardı edildiği klinik uygulamalarda çocuğun doğrudan bakımından sorumlu olan hemşireler, hastaneye yatan çocuk ve annelerinin yaşadıkları deneyim ve duyguların farkında olmalı ve psikososyal sorunları tanımlayabilmelidirler. Ayrıca hastanede yatış sürecinin her aşamasında çocuk ve annesini etkileyen faktörleri değerlendirebilmeli, sorunların erken saptanması ve sorunlara müdahale edilmesi konusunda aktif rol almalıdırlar. Araştırma sonuçlarının uygulamada kullanımı doğrultusunda;

- Hastanede yatan çocukların psikososyal semptomları açısından değerlendirilmesi,

- Çocukların hastaneye oryantasyonu için yaşına ve cinsiyetine uygun bilgilendirme ve desteğin sağlanması,

- Çocuğu hastanede yatan annelerin endişe düzeyini azaltacak ve oryantasyon sağlayacak bilgilendirme ve eğitimlerin yapilmas1,

- Özellikle uzun süreli hastaneye yatış gerektiren kronik hastalıklarda çocuk ve annelerinin birlikte değerlendirildiği çalışmaların yapılması,

- Yapılacak yeni çalışmalarda çocuğu hastanede yatan annelerin yaşadığı sorunların farklı değişkenler açısından da ele alınması önerilmektedir.

\section{Bilgilendirme}

Yazarların katkı oranı beyanı şu şekildedir: Tasarım G.Ü., L.K.; veri toplama ve kayıt G.Ü., B.A.; analiz ve yorum G.Ü.; makalenin yazımı G.Ü., B.A.; düzenleme ve danışmanlık L.K. tarafından yapılmıştır. Araştırmanın yapılabilmesi için bir üniversitenin girişimsel olmayan klinik araştırmalar etik kurulundan 20.06.2019 tarihli 33 sayılı karar nolu izin alınmıştır. Araştırma ile ilgili herhangi bir projeden ya da firmadan destek alınmamıştır. Araştırmanın bütçesi araştırmacılar tarafından karşılanmıştır. Yazarlar arasında herhangi bir çıkar çatışması yoktur. 


\section{Kaynaklar}

1. Akay AP, Emiroğlu FNİ. Kronik pediatrik hastalıklar ve hastaneye yatış. İçinde Çetin FÇ, Coşkun A, İşeri E, Miral S, Motavallı N, Pehlivantürk B ve ark., Çocuk ve Ergen Psikiyatrisi Temel Kitabı. Ankara: HYB Basın Yayın; 2008: $723-729$.

2. Bazzan JS, Milbrath M, Silva S, Tavares DH, Santos A, Thomaz MM. Family experiences during child hospitalization: an integrative review. Revista de Pesquisa, Cuidado é Fundamental Online 2020;12:1179-1186.

3. Santos PM, Silva LF, Bastos Depianti JR, Gallindo Cursino E, Ribeiro CA. Nursing care through the perception of hospitalized children. Revista Brasileira de Enfermagem 2016;69(4):603-609.

4. Theofanidis D. Chronic illness in childhood: psychosocial adaptation and family. Health Science Journal 2007;2:1-9.

5. Wilson ME, Megel ME, Enenbach L, Carlson KL. The voices of children: stories about hospitalization. J Pediatr Health Care 2010;24(2):95-102.

6. Bsiri-Moghaddam K, Basiri-Moghaddam M, Sadeghmoghaddam L, Ahmadi F. The concept of hospitalization of children from the view point of parents and children. Iranian Journal of Pediatrics 2011;21(2):201-208.

7. Çavuşoğlu H. Hastaneye yatmanın çocuk ve aile üzerindeki etkileri. İçinde Çavuşoğlu H, Çocuk Sağlığı Hemşireliği. Cilt 1. Sekizinci Bask1. Ankara: Bizim Büro Basımevi; 2004: 47-67.

8. Handayani A, Daulima NHC. Parental presence in the implementation of atraumatic care during children's hospitalization. Pediatr Rep 2020;12(11):11-14.

9. Lee YO. Hospitalization stress in child: concept analysis. Journal of the Korea Convergence Society 2020;11(1):327-335.

10. Üstün G, Erşan E, Kelleci M, Turgut H. Hastanede yatan çocuklarda psikososyal semptomların bazı değişkenler açısından incelenmesi. Cumhuriyet T1p Dergisi 2014;36(1):25-33.

11. Obaid KB. Psychosocial impact of hospitalization on ill children in pediatric oncology wards. IOSR Journal of Nursing and Health Science 2015;4(3):72-78.

12. Lau BWK, Tse WWC. Psychological effects of physical illness and hospitalization on the child and the family. Hong Kong Journal of Psychiatry 1993;3:9-18.

13. Kabukçu-Başay BK, Başay Ö, Ürüt A, Hasmercan B, Uysal M, Usul BE. Hastanede yatarak tedavi gören çocuklar: psikososyal uyumu etkileyen faktörler üzerine bir araştırma. Klinik Psikiyatri Dergisi 2020;24:402-413.

14. Üstün G, Kelleci M. Assessment scale for psychosocial symptoms in hospitalized children scale development, reliability and validity study. HealthMED 2013;7(7):2219-2228.

15. Erermiş HS. Hastalık karşısında çocuk ve ergen. İçinde Çetin FÇ, Coşkun A, İşeri E, Miral S, Motavallı N, Pehlivantürk B ve ark., Çocuk ve Ergen Psikiyatrisi Temel Kitabı. Ankara: HYB Basın Yayın; 2008: 730-737.

16. Quirino DD, Collet N, Neves AFGB. Hospitalização infantil: concepções da enfermagem acerca da mãe acompanhante. Rev gaúcha enferm 2010;31(2):300-306.

17. Kaynak H, Çövener Özçelik Ç. Ebeveynlerin hastanede yatan çocuklarının anksiyete düzeyine etkisi. HEAD 2020;17(4):312-316.

18. Lyu QY, Kong SKF, Wong FKY, You LM. Validation of Hospitalization Impact Scale among families with children hospitalized for cancer treatment. J Adv Nurs 2015;71(8):1958-1969.

19. Commodari E. Children staying in hospital: a research on psychological stress of caregivers. Ital J Pediatr 2010;36(1):4048.

20. Tehrani TH, Haghighi M, Bazmamoun H. Effects of stress on mothers of hospitalized children in a hospital in Iran. Iranian Journal of Child Neurology 2012;6(4):39-45.

21. Sarman A, Sarman E. Gözden kaçırılan bir konu: çocuğun hastanede yatmasının aile üzerindeki olumsuz etkileri ve önleyici hemşirelik yaklaşımları. Sağlık Bilimleri Üniversitesi Hemşirelik Dergisi 2020;2(2):113-120.

22. Günay O, Sevinç N, Arslantaş EE. Hastanede yatan çocukların annelerinde durumluk ve sürekli anksiyete düzeyi ve ilişkili faktörler. Turkish Journal of Public Health 2017;15(3):176-186.

23. Açıkgöz A, Ezen M, Söngüt S, Ulukuş A, Emir B. Çocuğu hastanede yatan annelerde anksiyete ve depresif belirtilerin değerlendirilmesi. ACU Sağlık Bilimleri Dergisi 2019;10(3):373-382.

24. Yüzer S, Yiğit R, Taşdelen B. Çocuğu hastanede yatan annelerin aldığı sosyal destek ile depresyon düzeyleri arasındaki ilişki. Anadolu Hemşirelik ve Sağlık Bilimleri Dergisi 2006;9(4):54-62.

25. Açıkgöz A, Şayık D, Söngüt S, Kaya Y, Köksal İ. Pediatri kliniklerinde refakatçi olarak kalan annelerin yaşadığı güçlükler ve hastanede kalmanın depresyon, anksiyete, stres düzeylerine etkisi. Kocaeli Medical J 2017;6(2):43-47.

26. Taşdemir Akkavak D, Sarıkaya Karabudak S. Hastanede yatan okul çağı çocukların hemşireyi ve hastaneyi algılama durumlarının incelenmesi. DEUHFED 2019;12(1):46-56.

27. Gönener D, Pek H. Okul yaş dönemi çocuğu olan ebeveynlerin hastalık ve hastaneye yatma durumunda "Ebeveynlerin Endişe Kaynakları Ölçeği”nin geliştirilmesi ve çocukların endişe kaynakları ile etkileşimi. Gaziantep Tıp Dergisi 2009;15(1):31-40.

28. Seval M, Kurt A. Duygusal zekâ düzeyinin çocuklarda hastanede yatmaya bağlı psikososyal semptomlar üzerindeki etkisi. OPUS Uluslararası Toplum Araştırmaları Dergisi 2019;14(20):743-762. 